\title{
STUDI PRODUKSI RADIOISOTOP Mo-99 DENGAN BAHAN TARGET LARUTAN URANIL NITRAT PADA REAKTOR KARTINI
}

\author{
Edi Trijono Budisantoso, Syarip \\ Pusat Penelitian dan Pengembangan Teknologi Maju
}

\begin{abstract}
ABSTRAK
STUDI PRODUKSI RADIOISOTOP Mo-99 DENGAN BAHAN TARGET LARUTAN URANIL NITRAT PADA REAKTOR KARTINI. Telah dilakukan analisis simulasi larutan U-nitrat sebagai target iradiasi neutron untuk produksi radioisotop Mo-99. Uranium dalam senyawa nitrat diperkaya dengan $20 \%$ berat U-235. Analisis simulasi dilakukan berdasarkan pada perhitungan program ORIGEN2 dimana variasi simulasi konsentrasi U-nitrat yang diuraikan dalam data komposisi unsur dalam larutan dijadikan masukan program ORIGEN2. Program ORIGEN2 digunakan untuk menghitung perubahan komposisi unsur apabila larutan teriradiasi neutron dengan fluks $5 \times 10^{11} \mathrm{n} / \mathrm{cm}^{2}$ det dengan lama iradiasi mulai dari 1 hari sampai dengan 8 hari. Untuk menyederhanakan analisis dibuat representasi grafis terhadap hasil perhitungan terhadap parameter K , Energi fisi, radioaktivitas MO-99 dan kontur peluruhan Mo setelah selesai iradiasi. Dari hasil analisis simulasi dapat disimpulkan bahwa radioisotop Mo-99 dapat diproduksi dengan melalui iradiasi larutan U-nitrat $102 \mathrm{~g} / \mathrm{l}$ dengan uranium diperkaya 20\% berat U-235 pada reaktor Kartini. Produksi yang dapat dicapai adalah $3.23 \mathrm{Ci}$ Mo-99 per 300 cc larutan dengan lama iradiasi 5 hari. Daya thermal yang dibangkitkan dalam larutan selama proses iradiasi sebesar 89.3 watt didinginkan oleh sistem sirkulasi air kolam reaktor.
\end{abstract}

\section{ABSTRACT}

STUDY FOR Mo-99 PRODUCTION BY IRRADIATING URANYL NITRATE SOLUTION AT KARTINI REACTOR. The analysis of U-nitrat as a neutron irradiation target to produce Mo-99 radioisotop has been simulated. Uranium in nitrate compound is enriched by $20 \%$ weight of U-235. Simulation nalysis is done by ORIGEN2 code calculation where the simulation variation of U-nitrat concentration elaborated in data of element composition in nitrate solution is made for the input of ORIGEN2 code. The code is used to calculate the change of element composition in the U-nitrat solution irradiated in the neutron with the flux of $5 \times 10^{11} \mathrm{ncm}^{-2} \mathrm{sec}^{-1}$ with the time variation from 1 day up to 8 days. To simplify, the analysis is made by graphical representation of the calculation result e.g. $K_{\sim}$, fisile power, radioactivity of Mo-99 and decay contour of Mo after finishing irradiation related to the time and U-nitrate consentration. From the simulation analysis result can be concluded that the Mo-99 can be produced in the Kartini reactor by irradiating $102 \mathrm{~g} / \mathrm{l}$ of U-Nitrat solution with uranium enriched by 20\% weight of U-235. The production is $3.23 \mathrm{Ci}$ Mo-99 per $300 \mathrm{cc}$ of solution by 5 days irradiation at Kartini reactor. The thermal power generation in the solution during irradiation process is equal to 89.3 watt is can be cooled by existing reactor core cooling system.

\section{PENDAHULUAN}

$\mathrm{H}^{\mathrm{in}}$ ngga sekarang ini kebanyakan Mo-99 dibuat dengan cara aktivasi U-235. Siapan terhadap target iradiasi ini dapat dibuat dalam berbagai variasi yaitu siapan U-235 dalam bentuk U-metal alloy atau U-235 yang dilapiskan secara elektroplating pada metal stainless steel.
Perbedaan bentuk siapan target iradiasi ini mempunyai keunggulan dan kekurangan masing-masing. Sebagai target iradiasi dalam bentuk U-metal alloy dalam mendapatkan radioisotop Mo-99 memerlukan proses pelarutan yang membutuhkan waktu yang lebih lama daripada proses pelarutan dari target iradiasi dengan U-235 yang dilapiskan pada metal stainless steel 
dengan cara elektroplating. Kekurangan pada siapan target iradiasi dengan cara elektroplating adalah pada kapasitas produksi yang kecil karena proses elektroplating hanya dapat memberikan lapisan U-235 dengan ketebalan dalam satuan $1 / 1000 \mathrm{~mm}$ pada luasan permukaan stainless steel. Kemungkinan lain bentuk target iradiasi adalah dalam bentuk larutan garam uranium. Dengan membuat bentuk target aktivasi sebagai larutan telah dapat memendekkan daur ekstraksi Mo-99 karena tidak memerlukan proses pelarutan. Pada tulisan ini akan dipelajari kemungkinan produksi Mo-99 dengan target iradiasi larutan garam uranil nitrat dengan uranium diperkaya dengan $20 \%$ berat U-235 dengan kekentalan larutan yang divariasi. Diharapkan dari perhitungan ini dapat diperoleh ukuran konsentrasi larutan uranil nitrat yang dapat menghasilkan radioisotop Mo-99 ekonomis dengan syarat keselamatan yang dapat dipertanggung-jawabkan.

\section{TATA KERJA}

Radioisotop Mo-99 adalah radionuklida buatan yang dapat diperoleh dengan banyak cara yang dapat dijelaskan seperti pada Gambar 1 sebagai berikut:

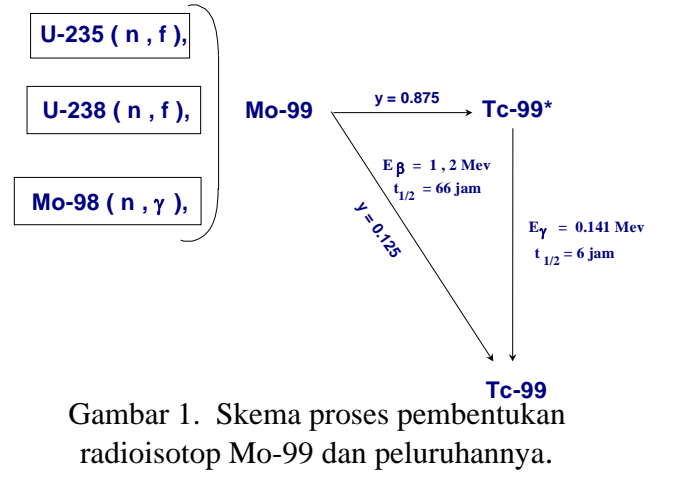

Kelimpahan radioisotop Mo-99 terbesar diperoleh dari hasil reaksi fisi pembelahan atom U-235. Radioisotop Mo-99 dalam peluruhannya menghasilkan radiasi beta dengan umur paro 66 jam membentuk anak luruh 87,5\% radioisotop meta stabil Tc-99* dan 12,5\% isotop Tc-99 stabil. Pada kegiatan kedokteran nuklir, radioisotop Mo-99 dimanfaatkan sebagai generator Tc-99* dengan menggunakan peralatan kolom penukar ion yang berperisai timah. Di dalam kolom tersebut radioisotop Mo-99 dengan radioaktivitas terukur disiapkan terikat (adsorbsi) dalam senyawa alumina $\left(\mathrm{Al}_{2} \mathrm{O}_{3}\right)$. Secara periodik radioisotop Tc99* dapat diambil dari kolom tersebut dengan cara pelarutan (elusi) sehingga menghasilkan larutan sodium pertechtenate $\left(\mathrm{NaTc}-99 * \mathrm{O}_{4}\right)$ yang steril dan bebas pyrogen. Radioaktivitas Tc-99* yang diperlukan dalam kedokteran nuklir adalah dalam jangkau 0,5-30 mCi. Aktivitas ini dapat digenerasikan dengan Mo-99 yang mempunyai radioaktivitas paling sedikit sama dengan radioaktivitas Tc-99* yang dibutuhkannya sehingga phenomena ini dapat menjadi pedoman untuk menentukan batas minimal tingkat radioaktivitas Mo-99 yang dibutuhkannya. Dalam tulisan ini akan dicoba kemungkinannya simulasi untuk memproduksi radioisotop Mo-99 dengan cara aktivasi atom U-235 pada teras reaktor Kartini yang mempunyai jangkau fluks neutron di teras reaktor pada nilai $5 \times 10^{11}-3 \times 10^{12}$ $\mathrm{n} / \mathrm{cm}^{2}$ det. Jangkau fluks neutron ini menentukan terhadap tingkat radioaktivitas Mo-99 yang didapat dari hasil aktivasinya.

Ujicoba simulasi dilakukan berdasarkan pada perhitungan paket program ORIGEN2 yang dikondisikan seperti teras reaktor Kartini. Input data program ORIGEN2 disusun sedemikian rupa sehingga program dapat menghitung seluruh ragam radionuklida yang terbentuk dalam larutan selama proses iradiasi di teras reaktor dengan fluks neutron teras dibuat sebagai tetapan sebesar $5 \times 10^{11}$ $\mathrm{n} / \mathrm{cm}^{2}$ det. ORIGEN2 juga digunakan untuk menghitung daya thermal yang dibangkitkan dan faktor multiplikasi neutron $(\mathrm{k} \sim)$ dalam larutan yang dapat digunakan 
sebagai parameter keselamatan. Dalam perhitungan simulasi ini larutan uranil nitrat ditempatkan dalam sebuah kapsul stainless steel yang mem-punyai bentuk menyerupai elemen bakar dengan kapasitas larutan 300 cc. Diagram kapsul ditampilkan pada Gambar 2.

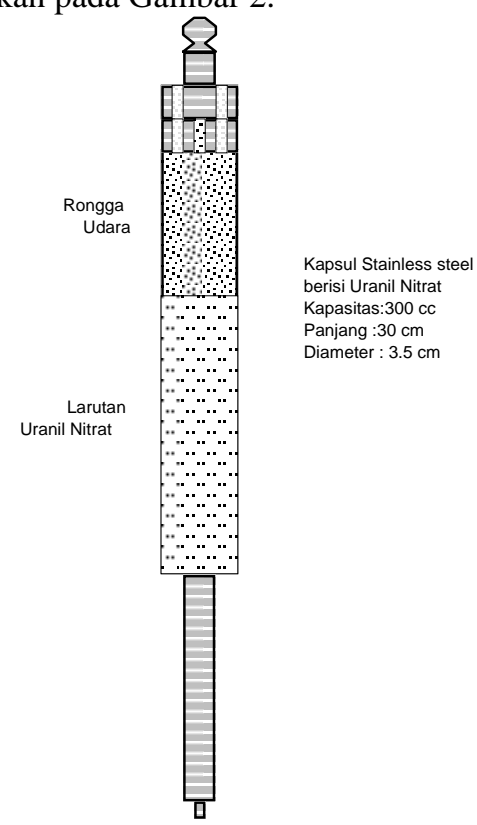

Gambar 2. Diagram kapsul stainless steel berisi larutan uranil nitrat untuk menghasilkan radioisotop Mo-99.

Nilai ekonomis laju pembentukan radioisotop Mo-99 di dalam kapsul dan tingkat keselamatan iradiasinya dihitung dengan program ORIGEN2 dengan membuat variasi konsentrasi uranil nitrat dalam larutan target iradiasinya. Parameter keselamatan ditentukan berdasarkan pada sifat multiplikasi neutron dalam larutannya dan tingkat daya yang dibangkitkan dalam kapsul. Bahan target aktivasi disimulasi sebagai larutan uranil nitrat dengan uranium diperkaya dengan 20\% berat U-235 dengan konsentrasi uranil nitrat dalam larutan divariasi.

Dalam keadaan normal uranil nitrat berbentuk kristal garam uranil nitrat heksa hidrate yang mempunyai senyawa kimia $\mathrm{UO}_{2}\left(\mathrm{NO}_{3}\right)_{2} 6 \mathrm{H}_{2} \mathrm{O}$ dengan titik leleh $60,2{ }^{\circ} \mathrm{C}$ dan titik didih $118{ }^{\circ} \mathrm{C}$, mempunyai rapat massa 2,807 g/cc. Kelarutan maksimum uranium dalam larutan adalah $660 \mathrm{~g}$ U/liter uranil nitrat atau sebanding dengan pelarutan 1394 g kristal uranil nitrat heksa hidrat menjadi satu liter larutan uranil nitrate.

Siapan target iradiasi dibuat dengan cara melarutkan kristal garam uranil nitrat ke dalam $\mathrm{H}_{2} \mathrm{O}$ dengan perbandingan berat masing-masing komponennya ditetapkan sesuai dengan konsentrasi uranil nitrat yang dikehendaki dalam larutannya. Formulasi perbandingan berat tersebut dibuat sebagai berikut:

$\mathrm{C} 1=\frac{X}{1000}\left(\frac{A_{U N}}{A_{U N}+A_{6 H_{2} O}}\right)$

$\rho_{l}=\frac{X+\left[1000-\frac{X}{\rho}\right]}{1000}$

dengan ketentuan

$X=$ berat $U$-nitrat yang dilarutkan (gr)

$\rho=$ rapat massa kristal $U$-nitrat

$C_{1}=$ konsentrasi $U$-nitrat yang dikehendaki sebesar $X$ (gr/liter)

$\rho_{1}=$ rapat massa larutan $U$-nitrat $(\mathrm{g} / \mathrm{ccc})$

$1000=$ volume larutan yang diperoleh $(c c)$

$\frac{A \cup N s}{A \cup N+A_{6} H_{20}}=$ fraksi uranil nitrate dalam UN-heksahidrate $=0,785$

Komposisi unsur dalam larutan U-nitrat ditetapkan berdasarkan pada perbandingan berat atomnya yang diformulasikan sebagai berikut:

$$
\begin{gathered}
m_{U-235}=\frac{20}{100}\left(\frac{X \cdot A_{U}}{A_{U}+14 A_{O}+2 A_{N}+12 A_{H}}\right) \\
m_{U-238}=\frac{80}{100}\left(\frac{X \cdot A_{V}}{A_{U}+14 A_{O}+2 A_{N}+12 A_{H}}\right) \\
m_{N}=\left(\frac{2 \cdot X \cdot A_{N}}{A_{U}+14 A_{O}+2 A_{N}+12 A_{H}}\right)
\end{gathered}
$$


$m_{O}=\left(\frac{14 \cdot X \cdot A_{O}}{A_{U}+14 A_{O}+2 A_{N}+12 A_{H}}\right)+\left(\frac{A_{O}\left(1000-\frac{X}{\rho}\right)}{A_{O}+2 \cdot A_{H}}\right)$

$m_{H}=\left(\frac{12 . X A_{H}}{A_{U}+14 A_{O}+2 A_{N}+12 A_{H}}\right)+\left(\frac{2 . A_{H}\left(1000-\frac{X}{P}\right)}{A_{O}+2 . A_{H}}\right)$

dengan ketentuan

$A_{U}=\frac{80 A_{U-238}+20 A_{U-235}}{100}$

$m_{U-235}, m_{U-238}, m_{N}, m_{O}, m_{H}=$ massa unsur-unsur dalam larutan (gram)

$A_{U-235}, A_{U-238}, A_{N}, A_{O}, A_{H}=$ nomor massa unsur dalam larutan

Komposisi material yang ditetapkan dengan formulasi (1) sampai dengan (6) adalah komposisi dalam 1000 cc larutan, sedangkan komposisi material dalam larutan 300 cc dapat diperoleh berdasarkan pada koreksi perbandingan volumenya.

Tujuan terhadap variasi konsentrasi U-nitrat tersebut adalah untuk mendapatkan komposisi larutan U-nitrat yang menghasilkan reaktivitas teras yang memenuhi syarat keselamatan teras reaktor Kartini.

Komposisi material larutan dijadikan data masukan program ORIGEN2 guna menghasilkan data sifat multiplikasi neutron, pembangkitan daya dan inventaris Mo-99 yang terbentuk dalam larutan.

\section{PERCOBAAN DAN HASIL}

Larutan U-nitrat dipersiapkan dalam variasi 6 tingkat konsentrasi larutan yaitu: 78,5 g/l, 102 g/l, 156,9 g/l, 235,4 g/l, 313,8 g/l dan 392,3 g/l. Komposisi material dalam masing-masing larutan ditampilkan pada Tabel 1. Program ORIGEN2 dipersiapkan untuk menghitung transmutasi inti unsur-unsur yang terjadi dalam larutan bilamana diradiasi dalam medan neutron dengan fluks $5 \times 10^{11} \mathrm{n} / \mathrm{cm}^{2}$ det dalam variasi waktu antara 1 sampai dengan 8 hari. Perhitungan ini mensimulasikan proses produksi radioisotop MO-99 di dalam sample U-nitrat yang di iradiasi di reaktor Kartini. Hasil perhitungan
ORIGEN2 me-liputi semua radioisotop hasil reaksi fisi dan hasil aktivasi neutron terhadap unsur-unsur di dalam larutan berikut energi fisi dan faktor multiplikasi neutron yang dihasilkan dalam larutan U-nitrat. Untuk analisis produksi Mo-99 dalam larutan, perhatian diberikan pada output ORIGEN2 yang menyangkut radioaktivitas Mo-99, faktor multiplikasi neutron dan energi fisi di dalam larutan target iradiasinya. Hasil pemilihan terhadap output ORIGEN2 ditampilkan secara grafis sebagai fungsi konsentrasi larutan, lama iradiasi dan lama peluruhan yang ditampilkan pada Gambar 3,4,5 dan 6. Dari hasil perhitungan tersebut dapat dipelajari pengaruh konsentrasi uranil nitrat dalam larutan terhadap produktivitas radioisotop Mo-99 dan keselamatan proses iradiasinya.

\section{PEMBAHASAN}

Uranium dalam larutan target iradiasi disimulasikan dengan pengkayaan 20\% berat U-235 sehingga ada potensi mengalami reaksi pembelahan dengan neutron dan menghasilkan energi fisi dan neutron baru. Energi fisi akan menghasilkan panas pada larutan target iradiasinya dan neutron baru akan mempengaruhi populasi neutron disekitar target iradiasinya.

Hasil perhitungan ORIGEN2 terhadap target iradiasi, menampilkan daya fisi larutan yang dipresentasikan secara grafis pada Gambar 3. Daya fisi yang dibangkit-kan dalam larutan berbeda-beda bergantung pada konsentrasi U-nitrat dalam larutannya. Pembangkitan daya ini memberikan pengaruh pada suhu larutannya yang dapat menggeser fasa cair pada larutan menjadi fasa campuran antara cair dan uap. Sistem pendingin larutan diperlukan untuk menjaga pergeseran fasa larutan tidak melebihi batas keselamatan kapsul iradiasinya.

Neutron baru yang dihasilkan oleh peristiwa pembelahan dalam target iradiasi 
akan menghasilkan peningkatan populasi neutron yang diperhitungkan sebagai reaktivitas positif. Prosedur pengoperasian reaktor mensyaratkan bahwa seluruh komponen reaktivitas teras harus terukur sehingga dapat diperhitungkan kesetimbangan antara reaktivitas negatif batang kendali dengan reaktivitas positif dari bahan bakar dan bahan lainnya dalam teras sehingga syarat keselamatan operasi reaktor dapat terpenuhi. Keberadaan reaktivitas positif yang ditimbulkan oleh sample iradiasi perlu diketahui nilai reaktivitasnya sehingga kontribusi keseimbangannya dapat terukur.

Dalam simulasi ini telah dibuat 6 macam variasi konsentrasi larutan U-nitrat sehingga dapat diketahui batas sifat multiplikasi neutron dalam larutan yang dapat memenuhi batas keselamatan iradiasi yang ditetapkan. Pada Gambar 4 ditunjukkan hasil perhitungan program ORIGEN2 terhadap faktor multiplikasi neutron dalam larutan sebagai fungsi konsentrasi U-nitrat. Pada gambar tersebut $\mathrm{K} \sim$ larutan akan makin tinggi apabila konsentrasi U-nitrat dinaikkan.

Secara grafis dapat diketahui konsentrasi larutan yang menghasilkan $\mathrm{K}$ sama dengan 1 terjadi pada konsentrasi larutan U-nitrat 102 g/l. Pada konsentrasi ini larutan U-nitrat tidak menyumbangkan reaktivitas positif di teras yang untuk sementara dapat diperkirakan sebagai batas konsentrasi larutan yang memenuhi syarat keselamatan target iradiasi di dalam teras reaktor Kartini tanpa membuat analisis keseimbangan reaktivitas terasnya..

Produktivitas Mo-99 dalam larutan dapat dikaji berdasarkan pada presentasi grafik hasil perhitungan ORIGEN2 terhadap larutan U-nitrat yang diiradiasi dalam medan neutron dengan lama iradiasi yang berbeda-beda. Presentasi grafik tersebut ditampilkan pada Gambar 5. Tampak pada gambar tesebut bahwa produktivitas Mo-99 dalam larutan didukung oleh tingkat konsentrasi U-nitrat dalam larutannya, makin tinggi konsentrasi U-nitrat dalam larutan akan menghasilkan radioaktivitas Mo-99 yang makin besar. Usaha untuk meningkatan produktivitas Mo-99 dengan meningkatkan konsentrasi U-nitrat dalam larutan perlu disertai dengan analisis keseimbangan reaktivitas teras karena berdasarkan pada Gambar 4, konsentrasi U-nitrat mempengaruhi sifat multiplikasi neutron pada larutannya.

Pada Gambar 5 dapat diketahui bahwa kenaikan radioaktivitas Mo-99 dalam larutan bergantung pada lama iradiasinya. Dengan umur paro 66 jam radioisotop Mo-99 dapat mencapai kejenuhan setelah mengalami lama iradiasi lebih dari 4 kali umur paronya. Berdasarkan pada Gambar 5 dapat diketahui bahwa pada lama iradiasi 8 hari radioaktivitas Mo-99 mulai mendekati pada batas kejenuhannya.

Gambar 5 tersebut menggambarkan hasil simulasi perhitungan radioaktivitas Mo-99 dari hasil iradiasi 300cc larutan U-nitrat dalam fluks neutron $5 \times 10^{11}$ $\mathrm{n} / \mathrm{cm}^{2}$ det. Apabila diperhitungkan lama iradiasi yang signifikan adalah 5 hari maka dalam kurun waktu iradiasi tersebut diperoleh radioaktivitas Mo-99 mencapai $2.5 \mathrm{Ci}$ sampai dengan $12.44 \mathrm{Ci}$ per $300 \mathrm{cc}$ larutan bergantung pada tingkat konsentrasi U-nitrat dalam larutannya. Pada konsentrasi larutan 102 g/l radioaktivitas Mo-99 yang dihasilkan sebesar 3.23 Ci per 300 cc. Sebagai hasil fisi, radioisotop Mo-99 terbentuk bersamasama dengan radioisotop Mo yang lainnya yang kebanyakan berumur paro lebih pendek. Untuk mendapatkan radioisotop Mo-99 yang murni memerlukan periode peluruhan yang dapat diperkirakan berdasarkan pada perbandingan radioaktivitas Mo-99 terhadap radioaktivitas total Mo. Hasil representasi grafik dari perhitungan ORIGEN2 yang ditampilkan pada Gambar 6, menunjukkan bahwa kebanyakan 
radioisotop Mo yang berumur pendek akan hilang setelah masa peluruhan 3 jam. Setelah lebih dari masa peluruhan tersebut radioisotop Mo sepenuhnya berasal dari radioisotop Mo-99 dengan umur paro 66 jam.

Dalam kedokteran nuklir Mo-99 digunakan sebagai generator radioisotop Tc-99 yang umur paronya 6 jam. Radioisotop Tc-99 diekstrak dari radioisotop induknya secara periodis setelah diperoleh batas kejenuhan akumulasinya yang memerlukan waktu kurang lebih 30 jam dari saat ekstraksinya. Minimal Aktivitas Mo-99 yang masih dapat digunakan dalam kedokteran nuklir adalah $30 \mathrm{mCi}$ sehingga produksi Mo-99 sebagai generator Tc-99 harus mempunyai aktivitas lebih besar dari 30.mCi.

Apabila ditinjau radioaktivitas Mo-99 dalam 300 cc larutan U-nitrat dapat mencapai 3.23 Ci dan menjadi $2.97 \mathrm{Ci}$ setelah 8 jam peluruhan, maka radioaktivitas Mo-99 tersebut dapat diolah menjadi radioisotop generator radiooisotop Tc-99 yang dapat dimanfaatkan dalam bidang kedokteran nuklir.

\section{KESIMPULAN}

Berdasarkan pada analisis simulasi program ORIGEN2 dapat disimpulkan bahwa radioisotop Mo-99 mempunyai kemungkinan dapat diproduksi di teras reaktor Kartini dengan target iradiasi larutan U-nitrat dengan konsentrasi 102 g/l dengan pengkayaan uranium 20\% berat U-235. Produksi yang dapat dicapai adalah 3.23 Ci Mo-99 per 300 cc larutan dengan lama iradiasi 5 hari. Daya thermal yang dibangkitkan dalam larutan selama proses iradiasi sebesar 89.3 watt didinginkan oleh sistem sirkulasi air kolam reaktor. Kesimpulan ini diperoleh sebagai studi awal terhadap kemungkinan produksi Mo-99 dengan bahan target larutan U-nitrat. Realisasi terhadap produksi radioisotop Mo-99, masih memerlukan beberapa penelitian lanjutan yang meliputi, desain kapsul iradiasi, perilaku fase larutan dalam medan neutron, perilaku fisika dan kimia larutan U-nitrat selama proses iradiasi dan pengujian keselamatan proses iradiasinya.

\section{ACUAN}

1. A.G. CROFF, A User Manual for The ORIGEN2 Computer Code, ORNL/ TM-7175, July 1980.

2. REAKTOR KARTINI, Laporan Analisis Kecelakaan Reaktor Kartini Tahun 1996, P3TM-BATAN, Yogyakarta.

3. HECTOR J. COLS Et. Al., Mo-99 From Low-Enriched Uranium, CNEA, Argentina.

4. MEDI-PHYSICS, INC., Product Information Issue, May, 1997

\section{LAMPIRAN}

Tabel 1. Komposisi unsur dalam larutan dengan berbagai konsentrasi U-Nitrat.

\begin{tabular}{|l|c|l|l|l|l|l|}
\hline No & Konsentrasi & \multicolumn{5}{|c|}{ Komposisi Unsur dlm 300cc larutan U-nitrat (g) } \\
\cline { 3 - 7 } & U-nitrat (g/l) & $\mathbf{H}$ & $\mathbf{0}$ & \multicolumn{1}{|c|}{$\mathbf{N}$} & $\mathbf{U}-238$ & U-235 \\
\hline 1 & 392.3 & 30.981 & 294.465 & 8.37 & 56.892 & 14.223 \\
\hline 2 & 313.8 & 31.268 & 280.612 & 6.693 & 45.513 & 11.378 \\
\hline 3 & 235.4 & 31.922 & 278.325 & 5.02 & 34.135 & 8.534 \\
\hline 4 & 156.9 & 32.391 & 274.439 & 3.348 & 22.757 & 5.689 \\
\hline 5 & 102.0 & 32.557 & 273.078 & 2.762 & 18.774 & 4.694 \\
\hline 6 & 78.5 & 32.722 & 270.818 & 2.1762 & 14.792 & 3.698 \\
\hline
\end{tabular}




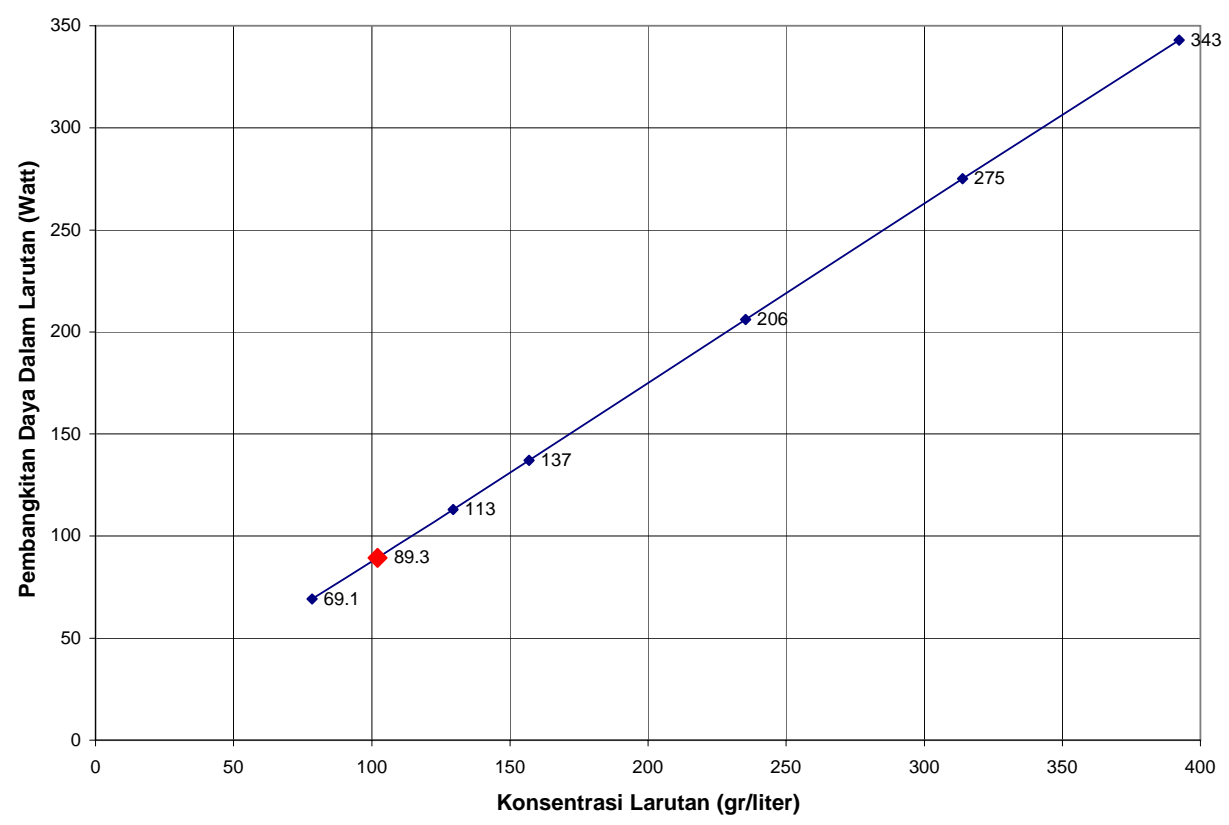

Gambar 3. Pembangkitan daya sebagai akibat proses fisi U-235 dalam larutan

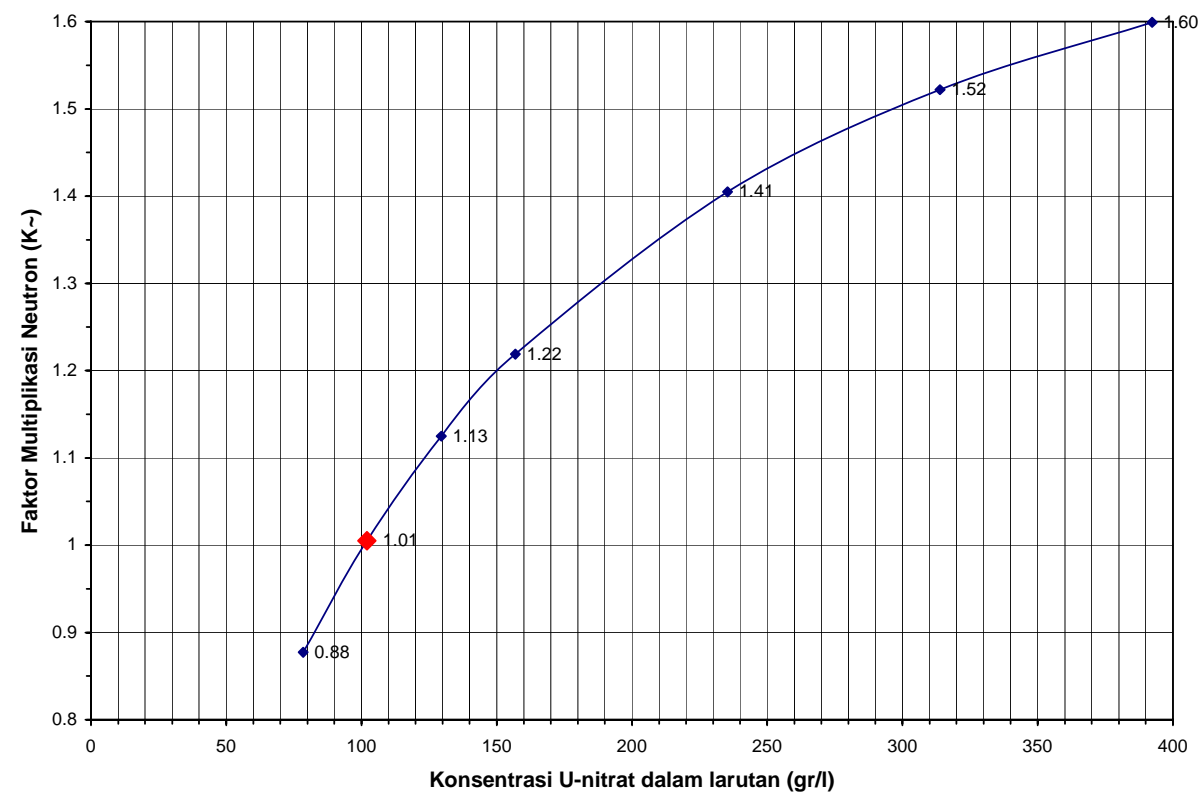

Gambar 4. Sifat multiplikasi neutron larutan dalam medan neutron yang dinyatakan dengan parameter 


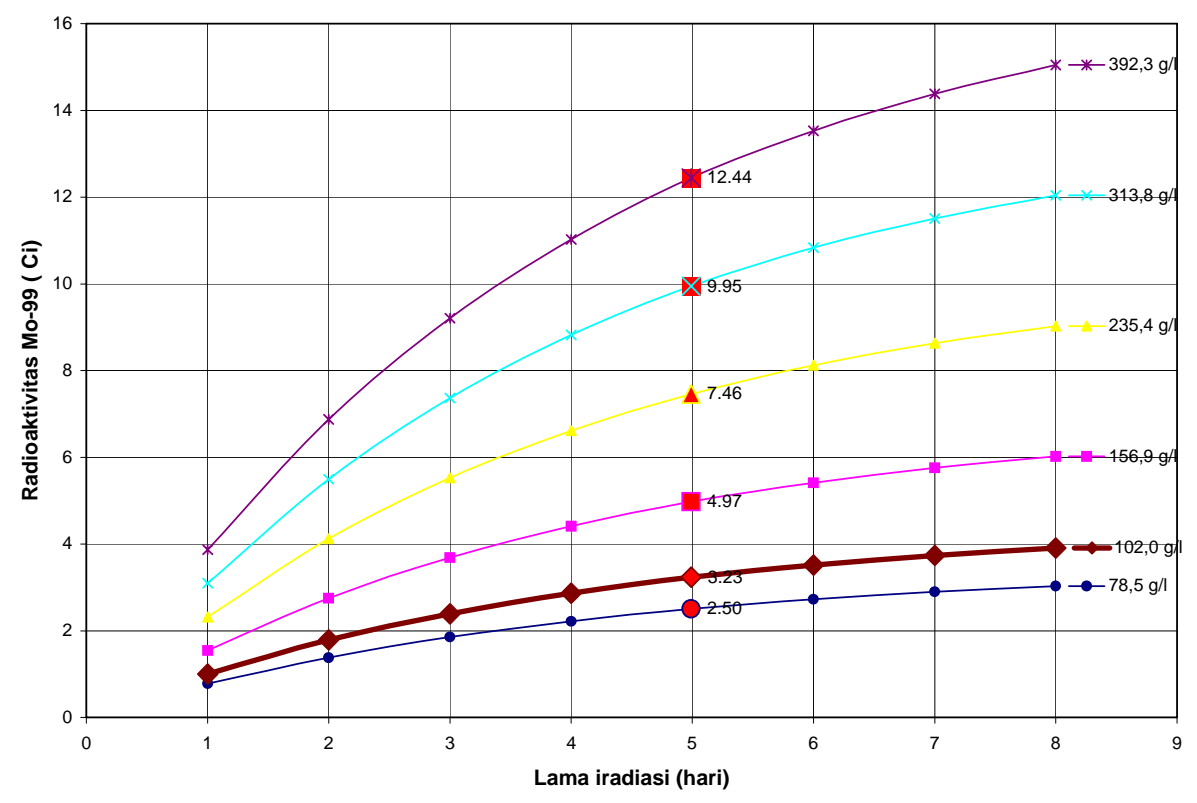

Gambar 5. Radioaktivitas Mo-99 selama proses pembentukan dalam larutan U-nitrat yang teriradiasi neutron dengan fluks neutron $5 \times 10^{11} \mathrm{n} / \mathrm{cm}^{2}$ det.

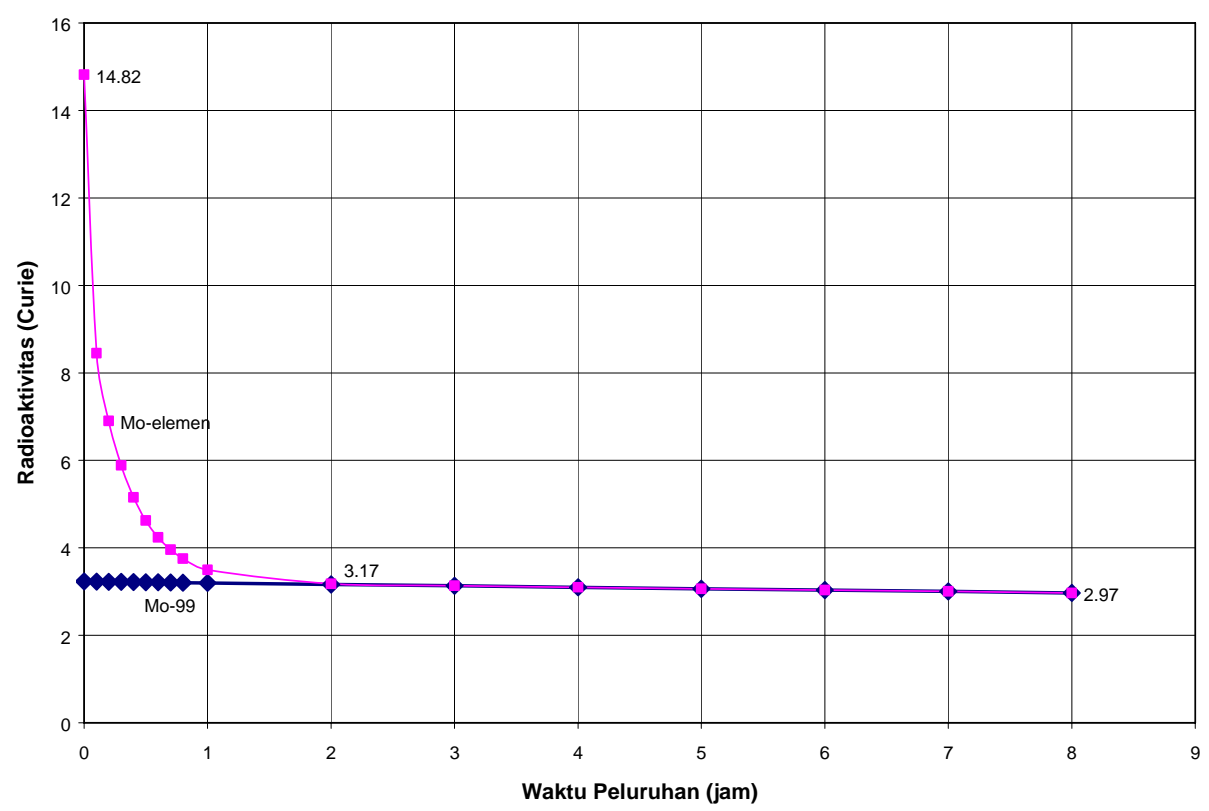

Gambar 6. Perluruhan radioisotop Mo-total dan Mo-99 dalam larutan U-nitrat 